\title{
Local Films as an Effort to Optimize Character Education
}

\author{
Vinda Maya Setianingrum \\ Universitas Negeri Surabaya \\ Surabaya, Indonesia \\ vindasetianingrum@unesa.ac.id
}

\author{
Tsuroyya \\ Universitas Negeri Surabaya \\ Surabaya, Indonesia \\ tsuroyya@unesa.ac.id
}

\author{
Puspita Sari Sukardani \\ Universitas Negeri Surabaya \\ Surabaya, Indonesia \\ puspitasukardani@unesa.ac.id
}

\begin{abstract}
Phenomenon is very clear now that millennial children hunt a lot of films in theaters. Not only as a lifestyle, but also as a necessity. While the reality in the Indonesian film industry is found the fact that more and more western films from Hollywood, Korean films, Indian films, and others. So the local film is worth educating to have a lot of work on. The Indonesian government must encourage film producers to fill cinemas with local films. Like the three films titled "Turah", "Jack" and "Yo wis Ben" whose local characters are strong. Films by raising the culture of Central Java and East Java and the film in Javanese or Regional languages. In line with the roadmap making Indonesia 4.0, which was launched by the Minister of Industry of Indonesia in April 2018, which demands the collaboration of all institutions and institutions to deal with Indonesia 4.0 era. One of them is encouraging the optimization of educational institutions to prepare technologybased education and human resources. Also hopes that education will still instill the character of the nation's generation If the education mapping is directed towards this matter, the role of producers in educating generations through local films is demanded. Millenials will indirectly learn a lot about ethics, culture and attitudes through film. Do not stop there, the presence of local figures or players also need to be reproduced in the film industry in Indonesia. The research question is how to optimize character education through local films as an effort to instill local ethics and culture for millennials. The research method is a case study by taking three local films in Javanese language and collecting data through interviews. The result is that Local Film plays an important role in efforts to improve character education for millennials. They love local language and cultured ethics more after watching the three films.
\end{abstract}

Keywords: Local film; character education; Javanese; Turah; Yo Wis Ben; Jack

\section{INTRODUCTION}

In 2018, the Indonesian film industry showed something different after the release of the film titled "Yo Wis Ben". Local films which almost 90 percent use Javanese are able to penetrate cinema screens competing with other national films. The enthusiasm of the people of Indonesia is very good. It was proven that within a few months the film showed 1 million viewers and became the first regional language film in Indonesia to reach 1 million viewers (www.tirto.id). This fact is surprising because it far exceeds the target imagined by the director and the film producer. The film, directed by Bayu Skak, a local young filmmaker from Malang, East Java, tells the story of the life of a youth band who has a big dream to be famous. The spirit to move forward and never give up finally led them to success. The dialogue in this film uses a local language called Javanese "wetanan" typical of Malang. The film location setting also uses Malang City although some players involve wellknown national film actors such as Cut Meriska and Joshua. The success of the local film "Yo Wis Ben" was also finally used by one of the candidates for the Governor of East Java to campaign for their work program. The Saifulah Yusuf and Puti Guntur Sukarno couple used the strategy of watching together this film in several locations to win the votes of the younger generation of millennials. Because as is known in 2018 is the political year of the election of the Governor and Deputy Governor of East Java, although the result is the pair lost the General Election held on June 27, 2018.

Beginning in 2019, the local content industry in Indonesia returned to squirm after the release of the film titled "Jack" which was screened in cinema and cinema XXI Indonesia. Film is set in the city of Surabaya, East Java and brings the story of student life in Surabaya and a dialogue that uses the Javanese language "Suroboyoan". The message raised about the tolerance of cross-ethnic life namely Arabic, Chinese, and Javanese becomes something that brings new hope that these stories are real in some regions in Indonesia and can be used as a medium for delivering messages (references). That the differences in religion and ethnicity is not a problem. Tolerance and mutual respect for each other is the key that peace can be realized. Moreover, the city of Surabaya as the capital of a province that is very urban, has a diverse cultural community, and is a city for higher education because there are many campuses in Surabaya. Although not as successful as the audience of the film "Yo Wis Ben" but the film "Jack" contains a message that teaches young millennials that real diversity exists around us and the community must understand that. 
Dialogue, communication, and social interaction are needed to be able to establish better social relationships.

The main message behind the cultivation of the local film that invites the importance of harmony between religions, tribes and languages. Teaches the importance of interacting with and understanding one another, about the love between children and parents. Children through Jack's character are initially quiet and lazy, then prove their affection by completing studies according to the expectations of their parents, while parents do not impose will for the future of their children. The same thing with the film "Yo wis Ben", thick local settings. Many messages in each dialogue segment are loaded with the value of hard work, unyielding and the importance of working together to achieve goals. In addition, it is also about the confidence of young people who are also fighting for their unique cultural characteristics, he said and his attitude remains a typical Javanese character of Malang, despite living in Jakarta. Previously the Indonesian film industry had been colored with a film titled "Turah" whose dialogue used Javanese version of the Central Javanese "kulonan". But this film was not as successful as the movie "Yo Wis Ben".

There is still a lot of value in the local character education that can be learned through the film. Of course that is part of the ideals of the directors. Making local films to rival or at least as a counterweight to the life references that can be watched by teenagers. So it is not just references to values and cultural characteristics of western or Asian culture that are embedded in the minds of Indonesian people. With the proliferation of foreign films, local films also need to be reproduced. So that they know the origin and traditions and noble values of the nation and it indirectly becomes a medium to remind and make aware of the importance of the culture, character and noble values of the nation. In other words, the cultivation of local films is a way to show the character of the nation's children which is sourced from the noble values of the Indonesian nation. The learning process can be obtained through film, especially if the film shows the unique cultural identity that is currently growing. Culture can come from historical values and pop culture [1].

The creative industry in Indonesia is currently experiencing a period of development and progress that continues to increase including the film industry. Public interest in a film showcases competitive filmmakers, where they are born to meet the needs of the film audience market which continues to demand new works to be able to compete with the film industry in the world. The number of Indonesian filmmakers and actress actors who played a role in the film festival at the international level proves that talents in Indonesia are able to contribute more, which is expected to provide new energy for improving film quality in the country [2]. In the 2000s the presence of widescreen films experienced a heyday, along with public awareness to enjoy Indonesian films. Because when it was known, the dominance of Hollywood cinema almost made Indonesian film industry suspended. Watching movies is starting to become a lifestyle of modern society. Films from the realm of Hollywood, Bollywood, to Indonesian films. Even thanks to advances in information technology that is increasingly rapid, ordinary people are able to make films perfunctory only through mobile phones.

Film as a medium of mass communication essentially conveys messages or communication material. To convey the message, the film is divided into several types. Films can be distinguished according to character, size, and segmentation [3]. With the development of film, the assumptions about the type of film increasingly diverse. When viewed from the contents of the film can be divided into fiction and non-fiction films [4]. The main elements consist of visual motion, audio, and storyline. the Storyline, unlike a still image that can be interpreted by the viewer himself, a cinematographic work relatively has universal meaning from the various viewers who see it. This is shown through a series of moving images containing the sequence of the storyline [5]. However, the storyline is also bound and limited by time constraints or the duration of the film. While the supporting elements films include settings, properties, and effects. Settings, or the environment where the picture was taken. Set is a layout that becomes a visual object for each scene. Is an element of the storyline reinforcement both naturally and taken in such a way (artificial) as part of the property [6].

\section{METHODS}

Type of research is qualitative descriptive with case study research methods. Case studies are types of research that provide a detailed description of the background and nature of an event. The main question raised by the author is in the form of "why and how." Data for case studies can come from interviews and field observations. In-depth faceto-face interviews aim to obtain data directly through questions raised by researchers [7]. Data collection techniques used interviews: Informants came from 10 student members of the film lovers community in East Java Indonesia including Kofie.com Surabaya State University, Kinne East Java Veterans National Development University, Epic University of Dr. Soetomo, “Graha Sinema” 17 August University of Surabaya, "Kineklub” University of Muhammadiyah Malang, Societo Sineklub Brawijaya University, "DKK" Art Council Faculty of Culture Jember University, Television and Film Student Association “Himafisi” Jember University, and “Koper IAIN” Jember.

\section{RESULTS AND DISCUSSION}

\section{A. Film as an Effective Media to Delivery Messages}

Film is one of the communication media that combines elements of sound and movement in one storyline and characterization style made by people for a group of other people [8]. The purpose of filmmaking is now very diverse, depending on the interests behind the making of a film, there are those who only provide entertainment, deliver educational and information messages. Although the film aspect of communication is one-way. But it is very influential for the audience. In certain situations, pictures and films can provoke or disturb the viewer, due to the dialogue that is constantly being raised for example about gender and culture that continues to be published [9]. With 
good film production techniques, it can provide a good audience experience as well. Thus, the audience seemed to experience it themselves or at least was forced to become a character in the film being watched.

The proof, when there are horror films, for example, many make the audience join in fear with the setting of horror scenes in the film. Goosebumps. Not a few, the effect of watching a horror movie makes the audience trapped in the experience in the film that is associated with everyday life. After watching, I was afraid to sleep alone, afraid of the dark, and other fears. In addition, watching sad or romantic films too, too carried away feelings until the film's story seemed to be experienced and felt by the audience, eventually joined in sadness and cried too. In fact, not a few also, people who change the character of speech, attitudes and behavior thanks to watching movies. There are individual differences that show that men will not frown when they see the horror of a horror movie. They will look relaxed and not show faces of fear. Men want to look brave in front of women. Their behavior is more due to the demands of the situation. While women will show expressions of horror more than men [10]. Do not stop there, the film also affects people's lifestyles through examples of values contained in the film [11]. Because of the reason for the effectiveness of this influence, lately many have produced films for commercial and market purposes. The film is a place for planting awareness in the community. The film is also to show dominance for certain countries. As published in previous studies, many attitude changes after watching the film. For example, films that feature scenes of rape sexual violence, there are differences in attitudes towards men and women. Men consider it only a traditional myth while women report a higher empathic attitude. Women experience significant changes in attitudes due to watching the film. This means that there is a change in attitude towards the audience after they watch a film [12]. Films can also reflect stereotypes for working women. Women who do not work and as housewives have weak stereotypes, low authority, and only as sexual objects. Whereas women working in films are reflected as having dominant stereotypes, having social interaction, and authority equal to men [13].

Research conducted with the informants of these students shows positive things that culture must be preserved, one of which can be through film. When asked about the moral values that can be taken from local films titled "Turah", "Yo Wis Ben" and "Jack", some informants conveyed the film has a moral message that local culture must be maintained. Indonesian people, especially teenagers, should be proud of the area where they come from. What culture does it have must be preserved. The local film also has a message value about the many differences and diversity that must be maintained by having a sense of tolerance. The community must realize that Indonesia has a diverse culture both in terms of language and local culture and it must be accepted by the Indonesian people themselves. One informant said he liked local films especially those titled "Yo Wis Ben" because in the film teaches that we must not give up on pursuing dreams and remain ourselves because that is precisely the asset we have. A community does not care where he comes from, even from the village area must remain confident because everyone has advantages. Another informant said local films such as "Yo wis Ben", "Jack" and "Turah" were only superior because they used the local language namely Central Java called Javanese "Kulonan" and East Javanese Malang Malang Surabaya called Javanese "Wetanan". The film "Yo wis Ben" predominantly uses the Javanese language typical of Malang, Jack uses the Javanese language typical of Surabaya, and Turah uses the Javanese language typical of Central Java. There was one informant who said he liked the film because of its locality and the rest there were no interesting messages in the film.

When asked to agree or not with films that raise local culture and language such as the film titled Turah, Jack and Yo Wis Ben who use dialogue in Javanese, all informants answered agree. Because if the film raises the culture and speech of various regional languages, it will show that the languages in each region are different. Although the distance between one region and another is geographically close, language and culture do not necessarily have in common. The informant strongly agreed with the film that raised the local culture, especially enjoyed in the national sphere in Indonesia. Because all Indonesian people know that the culture is part of Indonesia as well. So that they can respect and respect each other. One informant said he liked local films, especially titled "Turah" which uses the Javanese version of the Javanese dialogue in Central Java.

\section{B. Local Film as Character Education Character}

Education is a conscious effort to educate and instill values to the generation so that the nation's children can grow and develop with good behavior and character. Efforts to educate to instill good character can be done in many ways. Of course not only the responsibility of teachers in schools, religious teachers in the field of religion, or parents at home. But it must be a joint responsibility and needs to be pursued together. One that needs to be given attention in terms of character education is about changes in the character and lifestyle of the nation's children, which indirectly influences the values transmitted through the storyline that is broadcast in films in theaters. In a study, it is known that the cinematic imagery influences the process of nation-building. An analysis of complex interactions, reciprocal influences, and conceptual clashes between real and imagined spaces in these films reveals a strained relationship between the urban and the rural in the construction of national space [14]. As we all know, that the most film production and the most watched by Indonesian people are foreign films, such as Western Films and Asian films like Korea. Every Marvel-style outdoor film launch for example, cinema harvests the audience. Many tickets were sold out. Even many children to old people are also willing to queue for the sake of hunting for their favorite movie tickets. The closest example, that is, happened in the film Avengers.

As general understanding is known. Film is one of the communication media in addition to entertaining also for education and information. In fact, both of them are present together in an indeterminate form. Because educating is through entertainment. Educating can be to influence or can also contain teachings. Both, also cannot be separated. For 
example, in a film that tells about the relationship between parent and child can also be used as a message that the relationship between parent and child has the characteristics of each according to their culture and environment. There are parents who punish their children for discipline, there are also parents who use communication [15]. Because a lot of films worked on for industrial purposes. Therefore, the message conveyed through the film in addition to moral messages in the form of human values, there are also other values, such as lifestyle, speech and actions that indirectly affect patterns of interaction within the community. The more foreign films that are shown in theaters or watched by the public, the greater the chance that outside cultural values will influence and indirectly affect the community. Culture that is raised through film will continue to be a dominant value and hegemony the values of other societies.

Seeing the size of the influence of film on growing and developing the character of society. Then there needs to be new efforts to educate generations, educate people so that they are more characterless. People are the significant actor for building cultural identity [16]. One of them is through local films which are thicker with their own cultural values. Currently, local films can be counted on the fingers. Even in numbers far from outside films. Nevertheless, not a reason. Because, with the condition of the film set in a local setting as simple as the film "Yo wis Ben", "Jack", and "Turah" in fact, many enthusiasts and spectators. That means opportunity. Local films are popular with young people whose existence is to educate and strengthen the nation's cultural values to the community. Therefore, local films need to be worked out more optimally and innovatively but are still valuable to be a means to strengthen the character of the nation's children.

In this study, informants who were all students gave almost the same answers. When asked whether the characters and stories in the film being watched influence words and attitudes in daily life, most of the informants interviewed said that the film had an influence which was indirectly conveyed through dialogue messages in the film's story. Because what is watched will be a viewing experience for them and indirectly, consciously or not, will affect everyday life. Character and stories can also affect speech especially when the story was very close to everyday life. And lots of films that actually come from everyday life which are then developed into a visual story that can be enjoyed. If the characters in the story have something they like or admire, it can make a big impact on speech and attitude. The audience sometimes makes the character actors in the film as role models in everyday life [17]. An informant said that films can change attitudes but not continuously. Just a moment. Carried by the atmosphere and character of the film because of inspiration, and the audience experienced an incident like what they watched. There is also one informant who answered that he only enjoyed the film, enjoyed the roles and characters in each film shown, without having to imitate or influence his daily life. One informant said the film was very influential on the character of everyday life because of some new things that are obtained are implemented in social life. sometimes the directors and script writers intentionally give messages that are hidden in the film, and many are placed in characters, and become role models. Other informants said that moral messages in local films such as "Turah", "Yo Wis Ben", and "Jack" were highly valued because informants became more respectful of the language and cultural attitudes of the Javanese people in both Central and East Java. For example, not all habits that are considered bad by others are culturally bad. Other people just don't understand history and culture. Examples of the word "Jancok" in the culture "Suroboyoan" can also be used as a greeting word. While others who do not understand can consider the word as blasphemy. The film "Jack" brings a message that people learn about tolerance for diversity and must be able to make peace with these differences. Another informant said that if he truly fell in love with the film he was watching, then the film would affect his daily life, because this informant could like everything in the film, be it the style or language they used in the film. But if the film being watched is not interesting, then it is not so influential for his life.

When asked about the benefits of the three local films for daily life, most of the informants stated that after watching "Yo wis Ben", "Jack" and "Turah" theybecame aware that Indonesia had a wealth of culture and this needed to be preserved. The film also made the audience aware of mutual respect for each other, especially about their respective cultures. The audience also understands and increasingly knows about the diversity and differences that exist in Indonesia and even those differences are very close to them. From the local film "Yo Wis Ben" has a message that one should love himself more and not try to be someone else to be accepted by society. One informant said that the local films had no benefit, he was only happy to watch the film because he used Javanese dialogue and because he was Javanese. Another informant said that local films are useful for reflection in interpreting life. Maybe, the character of the player can change the attitude of the audience for the better, more freedom, more responsibility, and more respect for tolerance [18].

\section{The Future of Local Films in Indonesia}

When asked about what kind of films they like, whether foreign films (Hollywood, Indian films, or Korean films), Indonesian films, or local films, some informants said they liked local films because the stories featured were very close to adolescent's life so that it is easy to understand and can be taken as a positive example and support and appreciate Indonesian filmmakers themselves by watching Indonesian films in theaters or other alternative screens. In addition, many themes and issues raised in the local community. An informant said he prefers indie films in Indonesia because, indie films in Indonesia are made with very thick research without including commercial elements. The simplicity displayed in indie films without giving rise to the identity of filmmakers has its own value. One informant said that liking all films from any country and any genre depends on the content of the message because each film has its own value that is definitely different from one another. Films can also be taken from true stories, carrying messages that the public did not know before. Like the film Spotlight which finally made the public aware of sexual harassment that had occurred in a Catholic church. This film even got an Oscar in 2016 [19]. An informant claimed to be honest he preferred foreign films, because the stories they presented 
were not easy to guess and had very good plots. While Indonesian films still cannot reach this point, according to informants' knowledge in the Indonesian film industry. But sometimes local films are much better quality than feature films in Indonesia. Another informant said he preferred local films and Indonesian films because the packaging of the film was concise but not easy to guess. Local films still relate to his life, but did not rule out the possibility to watch films abroad.

When asked about the opinion of teenagers about films that raise local culture, whether it needs to be reproduced or what, most of the informants stated that it is very necessary as a promotional media of the local culture itself and as teenagers will be very happy if there are films that raise local culture. It is recommended that the amount of local film production continue to be reproduced and developed. Films with local culture are very necessary, given the increasingly boring pop culture. As Indonesian citizens, they should be obliged to maintain the local culture even if lifting it into the film would be something very interesting to watch and could be an education for those who don't know it yet. Every Indonesian citizen must be aware of nationalism and no longer intoxicated or proud of the incoming foreign culture. In addition, sometimes through its own film media, local cultures actually can eventually become interesting and make people aware, it turns out that Indonesia has a lot of unique local culture. Indonesian people must know that Indonesia has a lot of local culture. For example, in Java alone, there are still many different cultures and speech languages in each region. At this time films that raise local culture have begun to be noticed and have their own interests for the community. Culture can be better known through film now that Indonesian culture is more likely to watch than to read. Local films become one of the preservation of culture that can be immortalized so as not to be easily eroded eroded times. Local films must be reproduced to show that Indonesia is rich in culture. Films about local culture must indeed be lifted, especially now that film in Indonesia is on the rise, the interest of the audience to watch in the cinema is also high, it would be nice to provide education also about Indonesian culture, but by way of soft selling, not hard selling, because most viewers are lazy if hear or watch historical and cultural films. Local films such as "Yo Wis Ben" can be a passion for other regions in Indonesia to make similar things, namely films that are filled with their respective cultures and languages. In previous studies it was found that the strength of cultural connections could be an alternative conflict resolution. By understanding each other and appreciating other cultures, students will build a belief that differences shouldn't cause conflict. This cultural power has been applied in a class in which there are African and American students [20].

\section{CONCLUSION}

Film is a very effective message delivery media. Film is considered interesting because in it there are many elements of art including literary arts, drama, audio-visual arts, music, architecture, management, and fine arts. Because of the combination of several elements of the art, film was developed so rapidly along with the demand of the business industry that makes film production as a way to reap potential profits. Film has also become a way of life for today's society, especially teenagers. If there is free time and holidays, people schedule to watch certain films. But the facts so far in Indonesia, cinema is more dominated by Hollywood films that are culturally incompatible with the character of Indonesian society. Concerns about the negative influence of foreign films that could erode culture in Indonesia were later overcome by the emergence of films that raised local culture and content. Films with local Javanese languages such as the film Yo Wis Ben, Jack, and Turah are considered to be a new hope for the community especially teenagers that the culture in Indonesia is very rich and the community must be proud of the local culture. Local films also arouse the confidence of local young filmmakers to be able to make works that raise the stories of local communities with their individual characteristics and identities. From local films, people are expected to appreciate differences and increase tolerance in their daily lives.

\section{ACKNOWLEDGEMENT}

We would like to thank God for giving us the opportunity to write this article. We also would like to thank Rector and Dean of Faculty of Social Sciences and Law, Surabaya State University for supporting the authors to join the international conference. Lastly, we also would like to thank who has helped us finish this article and review this paper.

\section{REFERENCES}

[1] O. E. Lee and M. A. Priester, "Increasing Awareness of Diversity Through Community Engagement and Films,” no. June 2013, pp. 35-46, 2015.

[2] P. Aufderheide, Dokumentary Film - A Very Short Introduction. Oxford: University Press, 2007.

[3] M. Rizzo, The Art Direction Handbook of Film. London: Focal Press, 2005.

[4] B. Brown, Cinematography: Theory and Practice. London: Focal Press, 2012.

[5] P. Wheeler, Practical Cinematography. London: Focal Press, 2005.

[6] B. Cleve, Film Production Management, 3rd ed. London: Focal Press, 2006.

[7] R. K. Yin, Case Study Design and Method. Jakarta: Raja Grafindo Persada, 2004.

[8] J. Rosenbaum, Movie Wars. Acapella Books, 2000.

[9] S. G. Mehta, M. Balaji, and C. Sense, "Deconstructing Sitas Blues : Questions of Mis / representation , Cultural Property , and Feminist Critique in Nina Paleys Ramayana,” no. 2.

[10] D. Dosmukhambetova and A. S. R. Manstead, "Fear Attenuated and Affection Augmented: Male Self-Presentation in a Romantic Context,” pp. 135-147, 2012.

[11] I. Cury, Directing and Producing for Television. London: Focal Press, 2011.

[12] T. M. Emmers-sommer, L. Triplett, P. Pauley, A. Hanzal, and D. Rhea, “The Impact of Film Manipulation on Men's and Women's Attitudes Toward Women and Film Editing 1,” vol. 52, no. May, 2005.

[13] D. P. Freeman, Miriam L.; Valentine, "Through the Eyes of Hollywood: Images of Social Workers in Film," Soc. Work, vol. 49, no. 2, pp. 151-161, 2004.

[14] H. Shoham, “Urban Zionism in Early Hebrew Cinema,” vol. 26, no. 2, pp. 109-131.

[15] C. M. Rodriguez, "A Preliminary Evaluation of the Spanish Parent Child Aggression Acceptability Movie Task in Spain,” pp. 549-555, 2016.

[16] E. Franzia, Y. A. Piliang, and A. I. Saidi, "Manifestation of 
Minangkabau Cultural Identity through Public Engagement in Virtual Community,” Procedia - Soc. Behav. Sci., vol. 184, pp. 5662, 2015.

[17] J. Rose, "Understanding the Complexity of Love in Brokeback Mountain : An Analysis of the Film and Short Story,” vol. 14, no. 2, pp. 247-251, 2006.

[18] H. Potter, "Dumbledore's s Message,” 2001.

[19] B. A. Nesbit and R. Sorrentino, "Psychiatric Spotlight on Child Sexual Abuse,” pp. 3-6, 2016.

[20] R. Traoré and N. Carolina, "A n A lternative C ultural C onnections : to,” pp. 10-15, 1996. 